\title{
Vitamin D and Periodontitis: A Systematic Review and Meta-Analysis
}

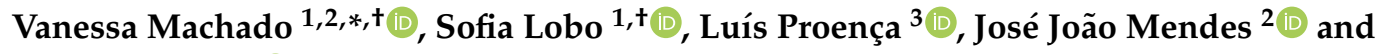 \\ João Botelho 1,2 (iD \\ 1 Clinical Research Unit (CRU), Centro de Investigação Interdisciplinar Egas Moniz (CiiEM), \\ Instituto Universitário Egas Moniz (IUEM), 2829-511 Almada, Portugal; sofiacllobo@gmail.com (S.L.); \\ jbotelho@egasmoniz.edu.pt (J.B.) \\ 2 Periodontology Department, CiiEM, IUEM, 2829-511 Almada, Portugal; jmendes@egasmoniz.edu.pt \\ 3 Quantitative Methods for Health Research (MQIS), CiiEM, IUEM, 2829-511 Almada, Portugal; \\ lproenca@egasmoniz.edu.pt \\ * Correspondence: vmachado@egasmoniz.edu.pt \\ + These authors contributed equally in this study.
}

Received: 19 June 2020; Accepted: 20 July 2020; Published: 22 July 2020

\begin{abstract}
To explore the vitamin D levels of periodontitis patients in comparison with periodontally healthy ones, and to assess the influence of vitamin D supplementation as an adjunctive during nonsurgical periodontal treatment (NSPT). Five databases (Pubmed, Embase, Scholar, Web of Sciences, and Cochrane Library) were searched until May 2020. Mean difference (MD) meta-analysis with corresponding 95\% confidence interval (95\% CI) and sensitivity tests via meta-regression were used. We followed Strength of Recommendation Taxonomy (SORT) to appraise the strength and quality of the evidence. Sixteen articles were included, fourteen case-control and two intervention studies, all reporting 25-hydroxyvitamin D $(25(\mathrm{OH}) \mathrm{D})$ levels. Compared with the healthy controls, the circulating $25(\mathrm{OH}) \mathrm{D}$ levels were significantly lower in chronic periodontitis patients (pooled $\mathrm{MD}=-6.80,95 \% \mathrm{CI}$ : -10.59 to -3.02 ). Subgroup analysis revealed differences among $25(\mathrm{OH}) \mathrm{D}$ measurements, with liquid chromatography-mass spectrometry being the most homogeneous method (pooled MD $=-2.05,95 \% \mathrm{CI}:-3.40$ to -0.71 ). Salivary levels of $25(\mathrm{OH}) \mathrm{D}$ showed no differences between groups. Due to the low number of studies, conclusions on aggressive periodontitis and in the effect of vitamin D supplementation after NSPT were not possible to ascribe. Compared with healthy controls, $25(\mathrm{OH}) \mathrm{D}$ serum levels are significantly lower in chronic periodontitis patients, with an overall SORT A recommendation. Future studies are needed to clarify the effect of vitamin D supplementation and the biological mechanisms linking vitamin D to the periodontium.
\end{abstract}

Keywords: vitamin D; vitamin D deficiency; 25(OH)D; periodontal disease; periodontitis; systematic review; meta-analysis

\section{Introduction}

Vitamin D is a fat-soluble hormone primarily obtained from exposure to sunlight, and additionally from the diet and nutritional supplements [1-3]. Vitamin D is a universal term employed to describe the compound that exhibits the biological activity of cholecalciferol in animals (vitamin D3). This vitamin is a key factor to the calcium-phosphate homeostasis regulation and mineral bone metabolism $[4,5]$. In this sense, vitamin D increases the intestinal absorption of calcium and decreases the secretion of parathyroid hormone, which consequently decreases systemic bone resorption [6,7]. In addition, vitamin D stimulates osteoblastic bone production and alkaline phosphatase activity, optimizes bone remodeling and covers bone mass by increasing bone matrix proteins $[2,3,8,9]$. 
Public awareness about vitamin D has increased over the last years due to the prevalence of its deficiency [3,10-14]. Accordingly, vitamin D deficiency may play an important biological and metabolic role in reducing bone mineral density, total mineral content, and, consequently, may represent a risk factor against bone healing $[3,14]$.

Periodontitis (PD) is a complex polymicrobial disease induced by an unbalanced interaction between the oral microbial and the individual inflammatory response $[15,16]$. The onset of this pandemic non-communicable disease $[17,18]$ is characterized by gum inflammation (gingivitis), and the progression results in loss of the supporting tissues of the teeth, and, if untreated, ultimately leads to tooth loss $[19,20]$. Furthermore, to prevent disease progression, to minimize symptoms and possibly to restore lost tissues, it requires a combination of periodontal therapeutic modalities according to patient periodontal status. The treatment can include oral hygiene instruction, subgingival instrumentation to remove plaque and calculus, local and/or systemic pharmacotherapy and periodontal surgery [21].

The nutritional consequences of vitamin D levels on periodontal health represent a matter of interest [22-27]. Over decades, lower vitamin D levels have been associated with higher periodontal destruction and severe periodontitis stages [28-36]. Others supported the idea that patients with higher levels of vitamin $\mathrm{D}$ were related to less bleeding on probing $(\mathrm{BoP})$ comparing to patients with lower levels [34]. In addition, in vitro studies demonstrated that vitamin D may decrease the number of Porphyromonas gingivalis through active autophagy [37] and might decrease the inflammatory burden of periodontitis in rodent models [38-41]. Furthermore, the association between vitamin D levels and periodontitis has been systematically investigated [42-45]; however, none of these studies were able to produce quantitative synthesis. Additionally, the impact of vitamin D supplementation during nonsurgical periodontal therapy (NSPT) has never been appraised in a systematic way.

Therefore, the aim of this systematic review was two-fold. The primary objective was to render robust synthesis on the association between vitamin D levels and periodontitis. The secondary objective was to assess the influence of vitamin D supplementation as an adjunctive during NSPT.

\section{Materials and Methods}

\subsection{Protocol and Registration}

This systematic review protocol was defined a priori and no deviations from the protocol were made. The work followed the Cochrane Handbook of Systematic Reviews of Interventions [46] and the report was made according to the Preferred Reporting Items for Systematic Reviews and Meta-Analyses (PRISMA) guidelines [47] (Supplementary Material Table S1).

\subsection{Focused Questions and Eligibility Criteria}

The following focused questions were addressed:

1. Are 25-hydroxyvitamin D (25[OH]D) levels associated with periodontitis?"

Chronic and aggressive periodontitis patients (Patients-P); periodontitis (Exposure-E); periodontal healthy patients (Comparison-C); serum and salivary 25-hydroxyvitamin D (25(OH)D) levels (Outcome-O).

2. "Does vitamin D supplementation have an adjunctive effect on NSPT?"

Patients with periodontitis supplemented with vitamin D (Patients-P); NSPT (Exposure-E); patients with periodontitis supplemented with placebo (Comparison-C); periodontal probing depth (PPD), clinical attachment loss (CAL), BoP levels (Outcome-O).

Inclusion criteria were determined as follows:

- Design: Intervention trials (randomized clinical trials (RCTs) and non-randomized studies of interventions (NRSI)) and observational studies (case-control, cohort studies);

- Studies in humans reporting 25(OH)D levels in patients with and without periodontitis; 
- Studies in humans reporting the effect of vitamin D supplementation as an adjunctive of NSPT;

- Studies describing vitamin D units of measurement and measurement methodology.

The search was conducted without any restrictions regarding year of publication or language.

\subsection{Search Strategy}

We searched Pubmed, MEDLINE (Medical Literature Analysis and Retrieval System Online), CENTRAL (The Cochrane Central Register of Controlled Trials), EMBASE (The Excerpta Medica Database), Web of Science from the earliest data available until May 2020. We merged keywords and the Medical Subject Headings (MeSHs) regarding the periodontal disease (periodontitis OR gingivitis OR periodontal health OR periodontal diseases [MeSH]) and Vitamin D (vitamin D OR (vitamin D [MeSH]) OR 25-hydroxy-vitamin OR calcitriol OR vitamin D supplementation OR Vitamin D deficiency OR vitamin D receptor) in accordance with the thesaurus of each database. Grey literature was searched through the OpenGrey portal [48]. Additional appropriate literature was included after a manual search of the reference lists of the final included articles. Periodontology-and nutrition-specific journals were hand-searched to identify additional articles.

\subsection{Study Selection and Data Extraction}

Two researchers (S.L. and V.M.) independently selected the relevant articles through titles and abstracts and excluded unrelated studies. A third author (J.B.) checked the eligible studies and any disagreement was resolved through discussion. If there were multiple publications for the same study, data from the largest sample were used.

Two researchers (S.L. and V.M.) independently extracted the relevant data from the studies. Any disagreement was resolved through discussion with a third researcher (J.B). A predefined table was used to extract necessary data from each eligible study, including the first author's name, publication year, the country where the study was conducted, exclusion criteria, number of participants, gender, mean age, percentage of smokers, periodontal case definition, sample type (saliva or serum), measurement of 25(OH)D levels and laboratory analysis. Clinical periodontal measures included PPD, CAL and BoP. All data were independently extracted by two reviewers with a consensus in all aspects. The authors were contacted for additional data clarification when necessary.

\subsection{Risk of Bias (RoB) in Individual Studies}

Methodological quality assessment was independently performed by two calibrated authors (V.M. and J.B.) using the Cochrane risk-of-bias tool 2 (RoB2) for RCTs [46] or ROBINS-I tool for NRSI [49]. For case-control and cohort studies, we used the Newcastle-Ottawa Scale (NOS). Regarding this last tool, we scored across three categories: studies with 7-9 stars were deemed of low RoB, studies with 5-6 stars of moderate RoB, whilst studies with less than 5 stars were deemed of high RoB. Any doubt was resolved by discussion with a third author.

\subsection{Statistical Analysis}

Statistical analysis was performed using R version 4.0.0 (R Studio Team 2018). For continuous data, mean values and standard deviations (SD) were used and analyzed with mean differences (MD) and correspondent estimates by $95 \%$ confidence interval $(95 \% \mathrm{CI})$. The unit of measurement used in the MD meta-analysis was $\mathrm{ng} / \mathrm{mL}$. In the case of median and interquartile range report, we converted to mean and SD following Hozo et al. [50]. DerSimonian-Laird random-effects meta-analysis [51] and forest plots were performed using the 'meta' package [52]. Statistical heterogeneity was inspected through the $\mathrm{I}^{2}$ index and Cochrane's $\mathrm{Q}$ statistic $(p<0.1)$. The overall homogeneity was calculated through the $\chi 2$ test [53]. All tests were two-tailed, with alpha set at 0.05 . Further, the weight percentage given to each study in each analysis was provided in the forest plots. Meta-regression was performed towards the influence of smoking in serum $25(\mathrm{OH}) \mathrm{D}$ levels. Publication bias was planned if at least 10 
or more studies were included [53]. In the case of lacking data amenable to meta-analysis, we followed the Synthesis Without Meta-analysis (SWiM) guidelines to synthesize quantitative data [54].

\subsection{Strength of Recommendations}

We employed the Strength of Recommendation Taxonomy (SORT) to appraise the strength and quality of the evidence [55]. The outcomes of the present systematic review, clinical recommendations, and future necessary research were discussed.

\section{Results}

\subsection{Study Selection}

Overall, the search yielded a total of 1531 studies (Figure 1). After duplicate removal, 1460 were screened for titles and abstracts, and 125 articles fulfilled the inclusion criteria (1335 were excluded). These 125 articles were subjected to full paper review eligibility and 109 were excluded as they did not approach the research questions (Supplementary Material Table S2). Then, 16 articles were included for the qualitative analysis, of which two concerned Vitamin D supplementation. A total of 13 studies were included in the quantitative synthesis regarding $25(\mathrm{OH}) \mathrm{D}$ levels in patients with and without periodontitis (Figure 1).

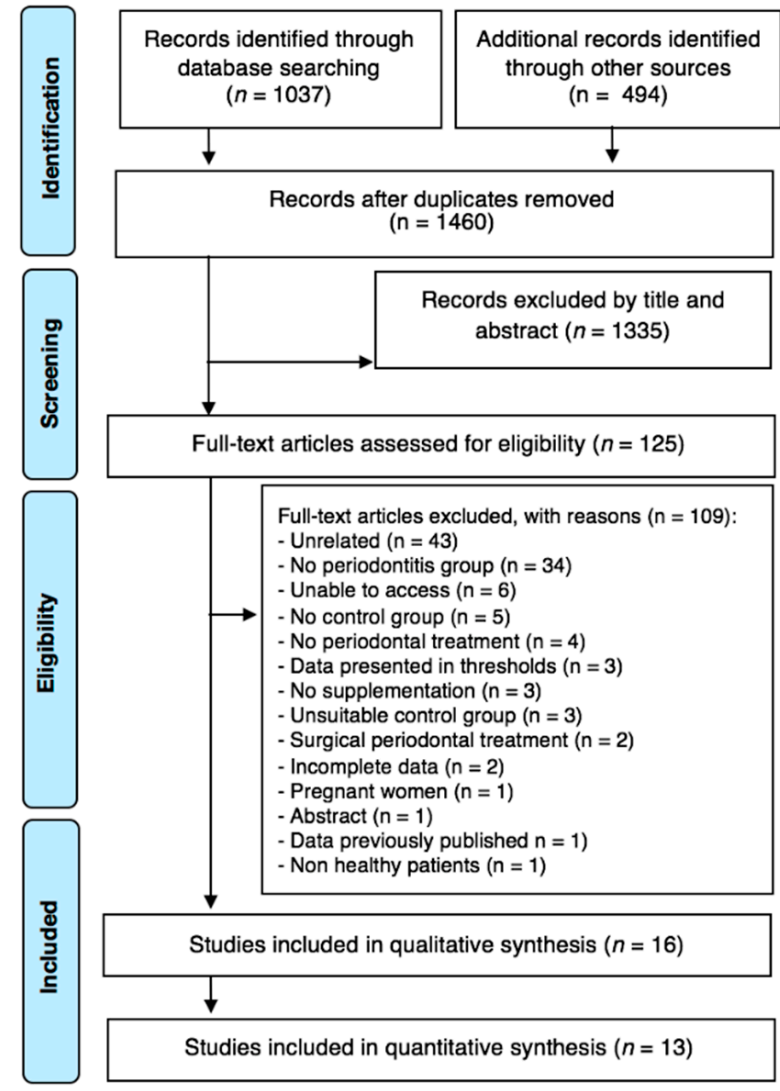

Figure 1. Article selection flow chart for the systematic review.

\subsection{Studies Characteristics}

Overall, the included case-control studies were from ten different countries, across Asia, Europe and America (Table 1), with a total of 10,597 participants included in this review. Two articles $[28,56]$ reported 91 aggressive periodontitis cases-one assessed the circulating 25(OH)D levels [28], and the other assessed salivary levels [56]. Quantitative analysis included a total of 10,506 subjects (subcategorised 
as 9718 periodontal healthy patients and 788 patients with chronic periodontitis) from 13 studies, of which three $[33,57,58]$ assessed $25(\mathrm{OH}) \mathrm{D}$ levels through salivary samples, nine through serum levels [28-32,36,59-61], and one assessed both methods [62].

In Vitamin D supplementation on NSPT, two studies were included [63,64]. Overall, 557 patients suffering from chronic periodontitis were submitted to NSPT and 276 participants were medicated with Vitamin D3 supplements. Gao et al. [63] searched the effect of two different concentrations of Vitamin D3 supplements in a controlled design (Table 2).

\subsection{Risk of Bias within Studies}

Thirteen articles presented with low RoB (four with 9/9, four with $8 / 9$ and five with $7 / 9$ scores) (Figure 2, Supplementary Material Table S3). Only one article presented moderate risk of bias, with an overall score of 6/9 [32]. The main reason for bias arose from the representativeness of the cases. Overall, articles adopted an adequate periodontitis case definition $(100 \%, n=14)$ and definition of control. A considerable number of studies failed to include representative samples $(57.1 \%, n=8)$ and the selection of controls $(42.9 \%, n=6)$. In the ascertainment of exposure, usability of the same method of ascertainment for cases and controls, and non-response rate, all articles presented low RoB $(100.0 \%, n=14)$. Two intervention trials presented low risk of bias, one RCT (Supplementary Material Table S4) and one NRSI (Supplementary Material Table S5).

\subsection{Synthesis of Results}

\subsubsection{Vitamin D Levels and Periodontitis}

\section{Serum Levels}

In our analysis, chronic periodontitis was associated with average lower serum 25(OH)D levels (MD of $-6.80,95 \%$ CI: $-10.59 ;-3.02)$, but with high heterogeneity $\left(\mathrm{I}^{2}=97 \%\right.$ ) (Figure 2 ). To mitigate the level of heterogeneity, we performed a subgroup analysis according to the method of $25(\mathrm{OH}) \mathrm{D}$ measurement (Figure 3). The liquid chromatography-mass spectrometry (LC-MS) method presented the lower differences and a moderate heterogeneity (MD of $-2.05,95 \% \mathrm{CI}:-3.40 ;-0.71, \mathrm{I}^{2}=41 \%$ ). The enzyme-linked immunosorbent Assay (ELISA) (MD of $-13.69,95 \% \mathrm{CI}:-24.86 ;-2.53, \mathrm{I}^{2}=97 \%$ ) and chemiluminescence immunoassay (CLIA) (MD of $-4.25,95 \% \mathrm{CI}:-6.69 ;-1.82, \mathrm{I}^{2}=54 \%$ ) presented higher differences but also higher heterogeneity. Univariate meta-regression found that the decrease in serum levels of 25(OH)D was not associated with smokers (Supplementary Material Table S6).

Due to the existence of only two articles $[28,56]$ regarding the comparison of serum levels of 25(OH)D of patients diagnosed with aggressive periodontitis compared to healthy periodontal patients, the meta-analysis was not deemed possible (Table 1). While one study [28] reported lower levels of 25(OH)D serum levels, the other, based on salivary measurements, showed opposite results [56].

Salivary Levels

Regarding salivary 25(OH)D levels, our analysis did not report differences comparing chronic periodontitis to healthy periodontal subjects (MD of $0.45,95 \%$ CI: $-1.05 ; 1.96$ ) (Figure 4). 
Table 1. Characteristics of the included studies regarding 25-hydroxyvitamin D (25(OH)D) levels.

\begin{tabular}{|c|c|c|c|c|c|c|c|c|c|}
\hline $\begin{array}{l}\text { Authors, Year, } \\
\text { Country }\end{array}$ & Funding & N. of Subjects & $\begin{array}{l}\text { N. of Healthy/ } \\
\text { CP/AgP }\end{array}$ & Male/Female & $\begin{array}{l}\text { Smokers } n \\
(\%)\end{array}$ & Mean Age \pm SD & $\begin{array}{l}\text { PD Diagnostic } \\
\text { Criteria }\end{array}$ & Method & Samples \\
\hline $\begin{array}{l}\text { Constantini et al., } \\
\text { 2020, Italy }\end{array}$ & None & 42 & 21/21/- & $14 / 28$ & $5(11.9)$ & $54.3 \pm 5.0 / 56.9 \pm 5.4 /-$ & EFP/AAP 2018 & ELISA & Saliva \\
\hline $\begin{array}{l}\text { Isola et al., } \\
2020, \text { Italy }\end{array}$ & University of Catania & 89 & $43 / 46 /-$ & $33 / 56$ & $24(27.9)$ & $53.7 \pm 4.5 / 53.1 \pm 4.2 /-$ & EFP/AAP 2018 & ELISA & Serum \\
\hline $\begin{array}{l}\text { Agrawal et al., } \\
\text { 2019, India }\end{array}$ & NR & 40 & 20/20/- & NR & $0(0)$ & $44.7 / 39.3 /-$ & $\begin{array}{c}\mathrm{GI} \geq 1, \mathrm{PI} \geq 1, \\
\mathrm{PPD} \geq 5 \mathrm{~mm} \text { and } \\
\mathrm{CAL} \geq 5 \mathrm{~mm}\end{array}$ & ELISA & Serum \\
\hline $\begin{array}{l}\text { Ketharanathan et al., } \\
2019 \text { (Tamil) }\end{array}$ & \multirow{2}{*}{$\begin{array}{c}\text { Institute of Clinical } \\
\text { Odontology, Faculty of } \\
\text { Dentistry, University of } \\
\text { Oslo, Norway }\end{array}$} & 48 & 21/27/- & $48 / 0$ & $2(4.6)$ & $41.1 \pm 5.7 / 42.6 \pm 6.7 /-$ & \multirow{2}{*}{$\begin{array}{l}\mathrm{CAL} \geq 6 \mathrm{~mm} \text { in } 2 \text { or } \\
\text { more teeth and } 1 \text { or } \\
\text { more sites with } \\
\mathrm{PPD} \geq 5 \mathrm{~mm}\end{array}$} & \multirow[t]{2}{*}{ LC-MS } & \multirow[t]{2}{*}{ Serum } \\
\hline $\begin{array}{c}\text { Ketharanathan et al., } \\
2019 \text { (Norwegian), } \\
\text { Norway }\end{array}$ & & 44 & 23/21/- & $44 / 0$ & $4(8.3)$ & $50.3 \pm 13.1 / 52.1 \pm 9.0 /-$ & & & \\
\hline $\begin{array}{l}\text { Ebersole et al., } \\
\text { 2018, USA }\end{array}$ & $\begin{array}{c}\text { U.S.P.H.S. grant } \\
\text { GM103538, GM103440, } \\
\text { and Center for Oral } \\
\text { Health Research } \\
\text { (University of Kentucky } \\
\text { College of Dentistry) }\end{array}$ & 9696 & 9308/388/- & NR & NR & NR & $\begin{array}{l}\text { NHANES 1999-2004: } \\
\text { CAL } \geq 3 \mathrm{~mm} \text { and } \\
\text { PPD } \geq 4 \mathrm{~mm} ; \\
1999-2000 \text { and } \\
2003-2004: \\
\text { PPD } \geq 3 \mathrm{~mm} \text { and } \\
\text { CAL } \geq 4 \mathrm{~mm} ; \\
\text { NHANES 2001-2004: } \\
\text { Page and Eke 2007 }\end{array}$ & LC-MS & Serum \\
\hline $\begin{array}{l}\text { Anbarcioglu et al., } \\
\text { 2018, Turkey }\end{array}$ & $\begin{array}{l}\text { Ondokuz May1s } \\
\text { University Scientific } \\
\text { Research Projects } \\
\text { Foundation }\end{array}$ & 156 & $27 / 55 / 74$ & $74 / 82$ & $0(0)$ & $\begin{array}{c}30.9 \pm 3.8 / \\
39.4 \pm 4.7 / 29.9 \pm 5.2\end{array}$ & AAP 1999 & LC-MS & Serum \\
\hline $\begin{array}{l}\text { Yuce et al., } \\
\text { 2017, Turkey }\end{array}$ & $\begin{array}{l}\text { Gaziosmanpasa } \\
\text { University Unit } \\
\text { of Scientific } \\
\text { Research Projects }\end{array}$ & 36 & 18/18/- & $18 / 18$ & $4(22.2)$ & $48.8 \pm 9.6 / 49.5 \pm 9.4 /-$ & AAP 1999 & ELISA & $\begin{array}{l}\text { Saliva and } \\
\text { Serum }\end{array}$ \\
\hline $\begin{array}{l}\text { Laky et al., } \\
\text { 2017, Austria }\end{array}$ & $\begin{array}{c}\text { Austrian National Bank } \\
\left(n^{\circ} .12986\right)\end{array}$ & 58 & 29/29/- & $20 / 38$ & $19(32.8)$ & $35.5 \pm 7.4 / 35.4 \pm 7.7 /-$ & $\mathrm{PPD} \geq 5 \mathrm{~mm}$ & ELISA & Serum \\
\hline
\end{tabular}


Table 1. Cont

\begin{tabular}{|c|c|c|c|c|c|c|c|c|c|}
\hline $\begin{array}{l}\text { Authors, Year, } \\
\text { Country }\end{array}$ & Funding & N. of Subjects & $\begin{array}{l}\text { N. of Healthy/ } \\
\text { CP/AgP }\end{array}$ & Male/Female & $\begin{array}{l}\text { Smokers } n \\
(\%)\end{array}$ & Mean Age \pm SD & $\begin{array}{l}\text { PD Diagnostic } \\
\text { Criteria }\end{array}$ & Method & Samples \\
\hline $\begin{array}{l}\text { Abreu et al., } \\
\text { 2016, Puerto Rico }\end{array}$ & $\begin{array}{l}\text { National Institute on } \\
\text { Minority Health and } \\
\text { Health Disparities of the } \\
\text { National Institutes } \\
\text { of Health }\end{array}$ & 38 & 19/19/- & $10 / 28$ & $0(0)$ & $46.7 \pm 8.2 / 47.6 \pm 8.7 /-$ & CDC-AAP 2003 & CLIA & Serum \\
\hline $\begin{array}{l}\text { Gümüş et al., } \\
\text { 2016, Turkey }\end{array}$ & $\begin{array}{l}\text { Research foundation of } \\
\text { Ege University, Izmir, } \\
\text { Turkey (n. 2013DIS029) }\end{array}$ & 42 & 27/15/- & $0 / 42$ & $0(0)$ & $25.0 \pm 4.0 /-/ 40.0 \pm 10.0$ & Armitage 1999 & ELISA & Saliva \\
\hline $\begin{array}{l}\text { Joseph et al., } \\
\text { 2015, India }\end{array}$ & $\begin{array}{l}\text { SBMR, Directorate of } \\
\text { Medical Education, } \\
\text { Government of Kerala }\end{array}$ & 98 & $48 / 50 /-$ & $46 / 52$ & $9(9,2)$ & $40.77 \pm 5.1 / 40.76 \pm 7.8 /-$ & Armitage 1999 & CLIA & Serum \\
\hline $\begin{array}{l}\text { Antonoglou et al., } \\
\text { 2015, Finland }\end{array}$ & $\begin{array}{l}\text { CIMO, Finnish Ministry } \\
\text { of Education and Culture, } \\
\text { Finnish Dental } \\
\text { Society Apollonia }\end{array}$ & 84 & 30/54/- & $32 / 52$ & $40(47,6)$ & $41.9 \pm 12.7 / 46.3 \pm 13.7 /-$ & - Page and Eke 2007 & CLIA & Serum \\
\hline $\begin{array}{l}\text { Miricescu et al., } \\
\text { 2014, Romania }\end{array}$ & $\begin{array}{c}\text { European Social } \\
\text { Fund and } \\
\text { Romanian Government } \\
\text { (POSDRU/6/1.5/S/S17) }\end{array}$ & 50 & $25 / 25 /-$ & $16 / 34$ & $0(0)$ & $18.66 \pm 2 /-/ 51.26 \pm 7.4$ & $\begin{array}{c}\text { At least } 6 \text { sites with } \\
\text { PPD } \geq 4 \mathrm{~mm} ; \\
\text { bone loss }>30 \% \text { and } \\
\text { gingival inflammation }\end{array}$ & ELISA & Saliva \\
\hline $\begin{array}{l}\text { Zhang et al., } \\
\text { 2012, China }\end{array}$ & $\begin{array}{c}\text { Natural Science } \\
\text { Foundations of China; } \\
\text { National Key Project of } \\
\text { Scientific and Technical } \\
\text { Supporting Programs of } \\
\text { China; Clinical Research } \\
\text { Fund, Ministry of Health }\end{array}$ & 76 & $32 /-/ 44$ & $29 / 47$ & $7(10,1)$ & $24.3 \pm 0.8 /-/ 26.8 \pm 1.7$ & $\begin{array}{l}\text { Classification of } \\
\text { Periodontal Diseases } \\
\text { and Conditions } 1999\end{array}$ & ELISA & Saliva \\
\hline
\end{tabular}


Table 2. Characteristics of the included studies regarding the $25(\mathrm{OH}) \mathrm{D}$ supplementation after nonsurgical periodontal treatment (NSPT).

\begin{tabular}{|c|c|c|c|c|c|c|c|c|c|c|}
\hline $\begin{array}{c}\text { Authors, } \\
\text { Year, } \\
\text { Country }\end{array}$ & Funding & $\begin{array}{c}\text { N. of } \\
\text { Subjects }\end{array}$ & $\begin{array}{c}\text { N. of } \\
\text { Control/CP }\end{array}$ & Male/Female & $\begin{array}{l}\text { Smokers } n \\
\quad(\%)\end{array}$ & Mean Age \pm SD & PD Diagnostic Criteria & PD Treatment & Method & Samples \\
\hline $\begin{array}{l}\text { Gao et al., } \\
\text { 2020, China }\end{array}$ & $\begin{array}{l}\text { Beijing Science and } \\
\text { Technology Program } \\
\text { and the National } \\
\text { Natural Science } \\
\text { Foundation of China }\end{array}$ & 240 & $120 / 120$ & $119 / 121$ & $5(11.9)$ & $\begin{array}{l}53.0 \pm 5.2 / 51.0 \pm 6.3 \\
53.0 \pm 5.2 / 49.0 \pm 5.4\end{array}$ & $\begin{array}{l}\text { At least } 6 \text { sites with } \\
\text { PPD }>6 \mathrm{~mm} \text {, } \\
\text { CAL }>4 \mathrm{~mm}, X \text {-ray } \\
\text { showing at least } 6 \text { sites } \\
\text { with alveolar bone loss } \\
\text { more than one third of } \\
\text { the root length }\end{array}$ & $\begin{array}{l}\text { Control-NSPT } \\
\text { and placebo; } \\
\text { Test group-NSP } \\
\text { and } 1000 \text { IU/day } \\
\text { vitamin D3 } \\
\text { Control-NSPT } \\
\text { and placebo; } \\
\text { Test group-NSPT } \\
\text { and 2000 IU/day } \\
\text { vitamin D3 }\end{array}$ & ELISA & $\begin{array}{l}\text { Serum (Baseline } \\
\text { and } 3 \text { months } \\
\text { after NSPT) }\end{array}$ \\
\hline $\begin{array}{l}\text { Perayil et al., } \\
\text { 2015, India }\end{array}$ & None & 77 & $41 / 36$ & NR & NR & NR & $\begin{array}{l}\text { One or more teeth with } \\
\text { chronic moderate } \\
\text { periodontitis, CAL of } \\
3-4 \mathrm{~m}\end{array}$ & $\begin{array}{c}\text { Control - NSPT } \\
\text { and placebo; } \\
\text { Test group-NSPT and } \\
60,000-120,000 \text { IU/day } \\
\text { vitamin D3 }\end{array}$ & ELISA & $\begin{array}{l}\text { Serum (Baseline } \\
\text { and } 3 \text { months } \\
\text { after NSPT) }\end{array}$ \\
\hline
\end{tabular}

CAL—clinical attachment loss; ELISA—enzyme-linked immunosorbent assay; IU—international unit; NR—not reported; NSPT-nonsurgical periodontal treatment; PPD—probing periodontal depth; SD—standard deviation. 


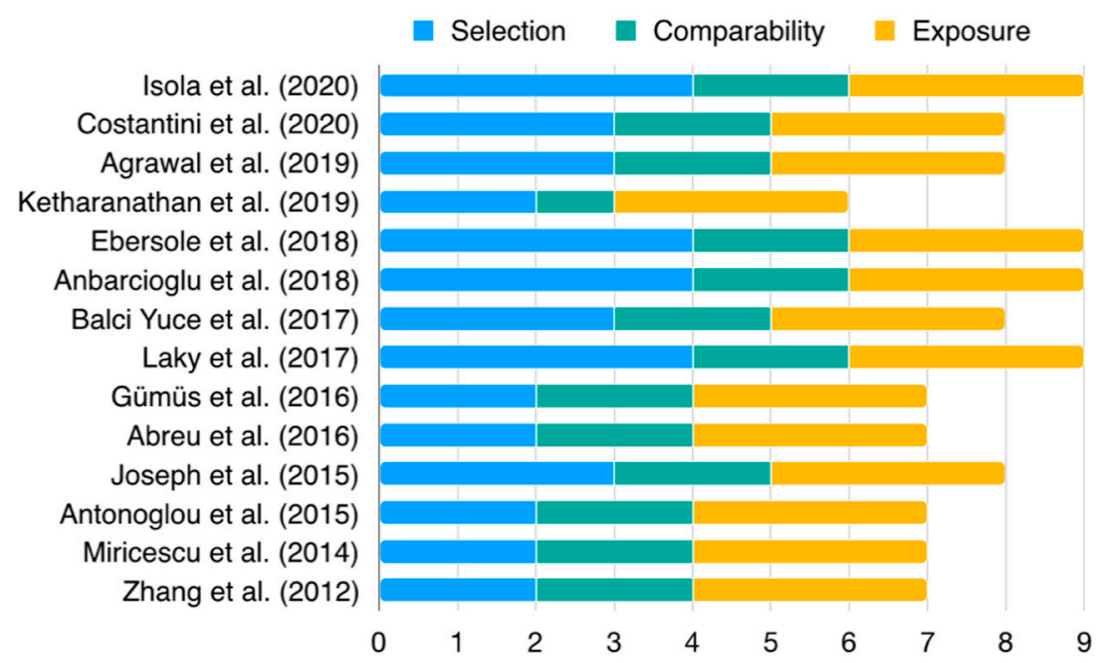

Figure 2. Newcastle Ottawa-Scale (NOS) for case-control studies. Detailed information is presented in the Supplementary Information (Table S3).

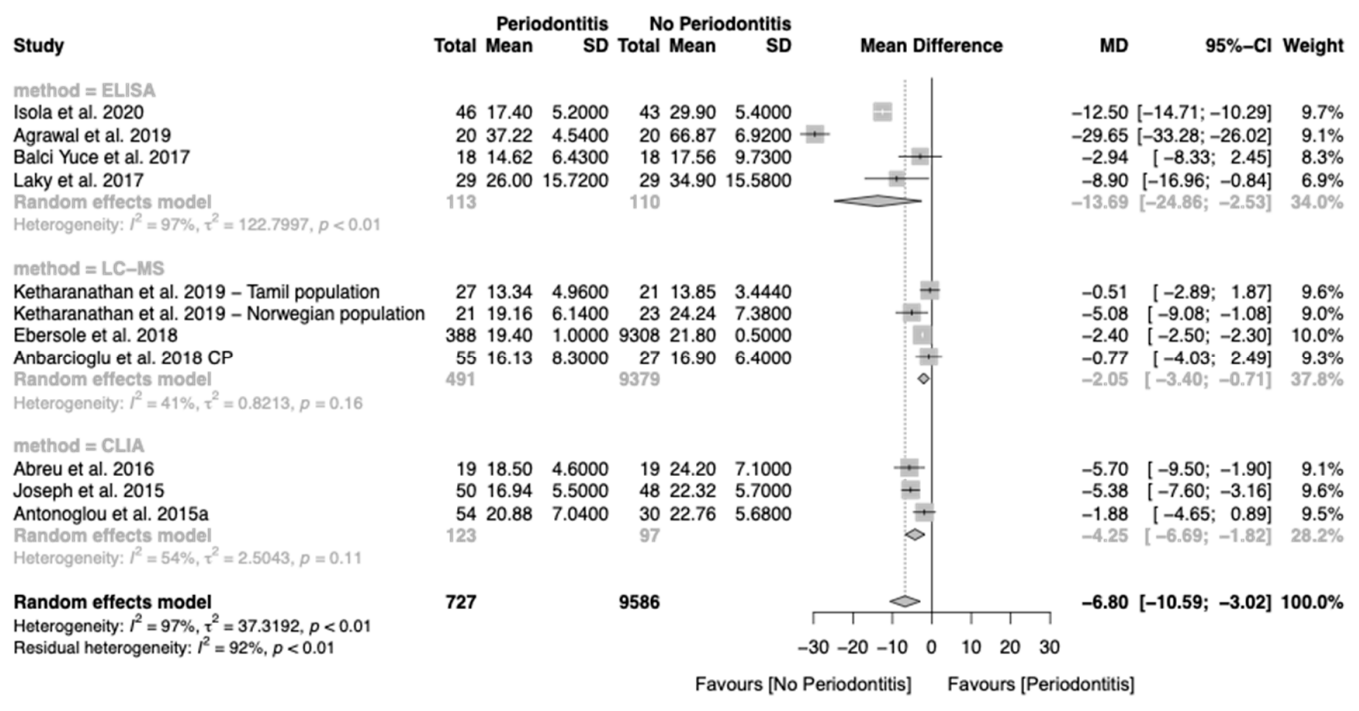

Figure 3. Forest plot of studies evaluating serum 25(OH)D levels in patients with and without chronic periodontitis ( $p$-value $<0.001$ ). Mean effect size estimates have been calculated with the correspondent $95 \%$ confidence intervals (95\% CI). Area of squares represents sample size, continuous horizontal lines and diamonds width represents $95 \% \mathrm{CI}$. The diamond and the vertical dotted line represent the overall pooled estimate.

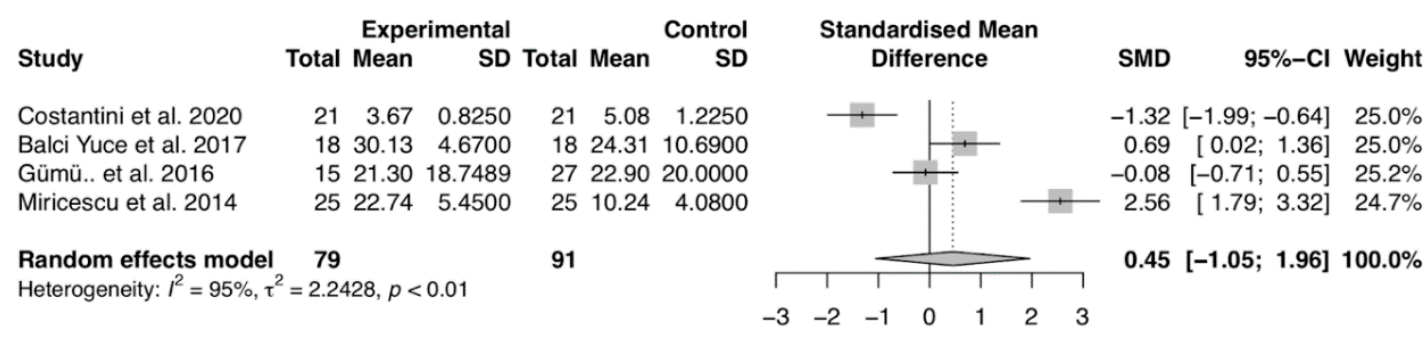

Figure 4. Forest plot of studies evaluating salivary 25(OH)D levels in patients with and without periodontitis ( $p$-value $=0.5545$ ). Mean effect size estimates have been calculated with $95 \%$ confidence intervals and are shown in the figure. Area of squares represents sample size, continuous horizontal lines and diamonds width represents $95 \%$ confidence interval. The diamond and the vertical dotted line represent the overall pooled estimate. 


\subsubsection{Vitamin D Supplementation as an Adjunctive in NSPT}

Due to the lack of data amenable to perform a meta-analysis about vitamin D supplementation on NSPT, we therefore decided to synthesize evidence without analysis. Two studies fulfilled the inclusion criteria, one RCT (Gao et al., 2020) and one NRSI (Perayil et al., 2015), both of low RoB (Supplementary Material Tables S4 and S5).

Gao et al. [63] applied vitamin D supplementation on 360 patients with moderate or severe periodontitis following NSPT. Patients were randomly assigned to 2000 international units (IU)/d vitamin D3, $1000 \mathrm{IU} / \mathrm{d}$ vitamin D3, or placebo. The effect of vitamin D supplementation tended to be modest with limited periodontal clinical relevance and long-term efficacy towards PPD and CAL (Gao et al., 2020).

Furthermore, Perayil et al. [64] investigated, in 82 moderate chronic periodontitis patients, if vitamin D supplementation plus calcium (Shelcal-D $500 \mathrm{mg}$ calcium + $250 \mathrm{IU}$ vitamin D once daily) compared to placebo following NSPT. Despite PPD and CAL having no differences between groups, the authors reported significantly better results for the vitamin $\mathrm{D}$ group in relation to gingival inflammation and bone density (measured using panoramic x-ray).

\subsection{Additional Analyses}

We confirmed that no publication bias was assessed in meta-analysis regarding the serum $25(\mathrm{OH}) \mathrm{D}$ levels $(p=0.1174)$ (Figure 5).

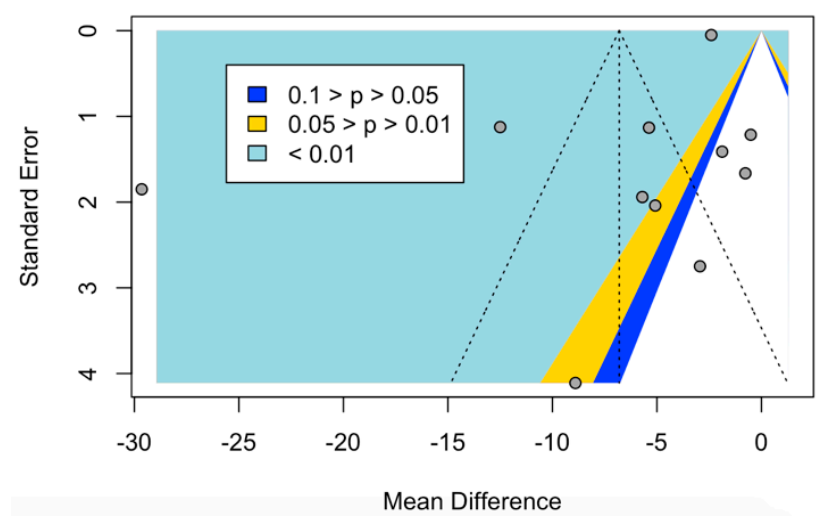

Figure 5. Funnel plot of studies evaluating serum vitamin D levels in patients with and without chronic periodontitis. Overall, this analysis showed no signs of publication bias.

\subsection{Reporting on Strength of Recommendation}

Using the SORT recommendation, we concluded that chronic periodontitis is strongly associated with lower serum levels of 25(OH)D (SORT A) [55].

\section{Discussion}

\subsection{Summary of Main Findings and Quality of the Evidence}

This systematic review supported an association between serum vitamin D levels (measured in $\mathrm{ng} / \mathrm{mL}$ of $25(\mathrm{OH}) \mathrm{D})$ and chronic periodontitis, with an overall SORT A recommendation. Within the lack of the available studies, salivary levels of $25(\mathrm{OH}) \mathrm{D}$ did not present an association with chronic periodontitis. In addition, there was a scarcity of studies regarding the association of aggressive periodontitis and $25(\mathrm{OH}) \mathrm{D}$ levels, and the influence of vitamin D supplementation precluded any definitive conclusion. Analyzing the impact of smoking in serum 25(OH)D level changes in chronic periodontitis, meta-regression analysis revealed that smoking had no meaningful impact. 
Overall, the results of this systematic review support a link between 25(OH)D serum levels and chronic periodontitis. That is, patients diagnosed with chronic periodontitis presented lower serum levels of $25(\mathrm{OH}) \mathrm{D}$ than periodontal healthy patients. These results are clinically relevant considering the crucial role of vitamin $\mathrm{D}$ in bone maintenance and in the immune system $[2,3,8,65,66]$. In addition, several studies have unveiled the potential harmful impact of vitamin D deficiency on the periodontium, especially after periodontal surgery where this baseline decrease might result in undesirable outcomes $[67,68]$.

A possible mechanism for this association whereby vitamin $\mathrm{D}$ reduces the risk of periodontitis is through the induction of cathelicidin [69-73]. The vitamin D pathway has been shown to exist in human gingival fibroblasts and periodontal ligaments cells, playing an important role in immune defense in periodontal soft tissues via the activation of the human cationic antimicrobial protein cathelicidin [69-72]. Recently, serum 25(OH)D deficiency was associated with decreased hBD-2 and cathelicidin levels in periodontal tissues in gingivitis and chronic periodontitis [73].

Several limitations, however, should be reported. Firstly, the level of heterogeneity observed was high and can limit the validity and robustness of these quantitative analyses. The lack of consistency in the periodontitis case definition precluded more robust analyses of the extent and severity of periodontitis with $25(\mathrm{OH}) \mathrm{D}$ serum levels. Thus, future studies should accommodate the up-to-date consensus [74], because of its upgraded characteristics [75,76], as well providing more in-depth data on the extent and severity of periodontitis and its relevant periodontal clinical measures (such as PPD, $\mathrm{CAL}$ and BoP). Secondly, the main analysis in this systematic review was derived from observational studies, that only inform the association between periodontitis and $25(\mathrm{OH}) \mathrm{D}$ serum changes. Therefore, studies with longer follow-ups are mandatory to clarify this matter. Furthermore, the included studies showed multiple quantification method of $25(\mathrm{OH}) \mathrm{D}$ levels, and this may have contributed to the heterogeneity. In the future, studies should harmonize the measurement method of $25(\mathrm{OH}) \mathrm{D}$ levels. On the other hand, there are strengths in this evidence-based study. This review was designed a priori and followed a strict protocol, updated international reporting guidelines, and had an extensive literature search.

Considering the existing evidence, this is the first review to render a magnitude effect on the association between serum 25(OH)D levels and chronic periodontitis. Overall, four systematic reviews have analyzed such association [42-44,77], but without success in pursuing meta-analysis. Further, these reviews have reported contradictory conclusions, wherein Van der Putten et al. (2009) found no evidence of an association of vitamin D with periodontal disease in non-institutionalized elderly people, Pinto et al. [44] and Perić et al. [43] found insufficient data to provide a conclusion, while Varela-López et al. [77] reported a potential association.

With regard to periodontal treatment, our narrative synthesis provides a small view on the potential characteristics of vitamin D supplementation on NSPT. One the one hand, the shortage of literature was already highlighted, which precludes any conclusion on the effect of serum vitamin D levels on periodontal treatment [43,78]. On the other hand, a previous review found that baseline vitamin D deficiency at the time of the periodontal treatment, especially in surgical procedures, negatively affected treatment outcomes [45]. However, more randomized clinical trials are warranted to provide a robust conclusion.

\subsection{Clinical and Research Implications}

Public awareness of vitamin D levels is high due to the worrisome prevalence of vitamin D deficiency worldwide $[3,10,11]$. Nevertheless, it is important to highlight that to confirm the decreased total levels of $25(\mathrm{OH}) \mathrm{D}$ in a more complete way, studies may combine total $25(\mathrm{OH}) \mathrm{D}$ with parathyroid hormone (PTH), calcium and phosphate levels [79]. Thereafter, the results of this systematic review are clinically relevant because they link these low vitamin D levels to chronic periodontitis, an inflammatory condition that figures as one of the most prevalent disease in the world $[18,80]$. In other words, periodontitis patients are very likely to have lower serum levels of $25(\mathrm{OH}) \mathrm{D}$, though 
the clinical consequences are still unclear in their entirety, and for this reason larger and well-designed RCTs are warranted.

Vitamin D levels have been consistently associated with several systemic diseases, such as rheumatic [81-83], cardiovascular [84-87], diabetes mellitus [87-89], inflammatory bowel disease [90,91], or female-related conditions [92-95]. Further, other factors such as seasonal variation [96], race and vitamin D binding protein [97] can also affect 25(OH)D levels. Likewise, periodontitis is also a relevant risk factor in these pathologies [98-105], and a potential mediation effect of periodontitis-vitamin D may be considered and further developed in clinical studies.

Our results can also serve as clinical and research guidelines for expected differences in vitamin D levels in periodontitis patients, as well as clarifying the importance of knowing the method to measure vitamin $\mathrm{D}$, as this may impact vitamin D differences. At this stage, the LC-MS measurement method showed moderate heterogeneity (I2 $=41 \%$ ), regardless of the multiple periodontal diagnostic criteria observed in this subgroup; therefore, we might expect more homogeneous results when studies employ the same case definition $[28,30,32]$. In view of these results, LC-MS might be seen as the most consistent method to measure 25(OH)D serum levels, both in clinical practice as well as in research studies, and is in agreement with a previous reliability study on vitamin D quantification [106].

While $25(\mathrm{OH}) \mathrm{D}$ serum levels of periodontitis patients were decreased compared to healthy controls, the $25(\mathrm{OH}) \mathrm{D}$ levels in whole saliva had no significant differences, and the results of the included studies are quite heterogeneous in saliva. A reasonable explanation for such differences can be the expression of vitamin-D binding protein (DBP) locally versus systemically. In this sense, a previous study on healthy periodontal patients showed that the levels of DBP in gingival crevicular fluid were higher than serum levels [107], and therefore periodontal tissue might be another source of DBP [108]. Furthermore, the levels of DBP were found to be lower in periodontitis cases, presumably due to the lack of effective production or an increase in local consumption [107]. The results on salivary levels show some heterogeneity among the studies, in particular $[33,58]$, as well a low number of participants, which limits the validity of this finding. A possible explanation for the discrepancy between Miricescu et al., 2014 [58] and Costantini et al., 2020 [33] is the difference between mean age, gender distribution and periodontal diagnosis between these two studies.

Notwithstanding these issues, more studies are warranted to explore the role of DBP expression on the salivary and serum levels of $25(\mathrm{OH}) \mathrm{D}$ on periodontal patients.

Mindful of the inflammation surrounding teeth, peri-implantitis is a pathological condition characterized by the progressive loss of supporting peri-implant bone [109], and strong evidence has suggested that PD is a risk factor for implant loss [110]. A single study found that 25(OH)D levels are significantly decreased in peri-implantitis patients comparing with peri-implant healthy patients and, consequently, might be important indicators of peri-implant diseases [111]. Nevertheless, further studies are needed to confirm if such an association with vitamin D follows the same fashion as PD.

Importantly, future studies on the impact of vitamin D supplementation should bear in mind the baseline status of the patients. Currently, vitamin D supplementation studies support the arbitrary application of vitamin D supplements as an adjunct in NSPT, though studies have seemed to disregard the baseline vitamin D levels, and this might lead to inevitable bias of analysis. In this sense, future studies should define a priori which patients have vitamin D deficiency $(<20 \mathrm{ng} / \mathrm{mL})$ or insufficiency $(<30 \mathrm{ng} / \mathrm{mL})$ to clarify whether the restoration of DV levels will result in superior periodontal clinical results. Moreover, studies must consider the initial periodontal status and the interplay of $25(\mathrm{OH}) \mathrm{D}$ with key periodontal clinical measures. Therefore, intervention studies using vitamin D supplementation should define with a clear threshold alike patients according to the baseline 25(OH)D levels and the periodontal status. 


\section{Conclusions}

Periodontitis is associated with lower $25(\mathrm{OH}) \mathrm{D}$ serum levels. The effect of vitamin D supplementation as an adjunct of nonsurgical periodontal treatment remains unclear due to the shortage of available studies. Future studies are needed regarding the effect of vitamin D supplementation and the biological mechanisms linking vitamin $\mathrm{D}$ to the periodontium.

Supplementary Materials: The following are available online at http://www.mdpi.com/2072-6643/12/8/2177/s1, Table S1. PRISMA 2009 Checklist; Table S2. List of potentially relevant studies not included in the systematic review, along with the reasons for exclusion; Table S3. Newcastle-Ottawa Scale; Table S4. RoB2 Tool; Table S5. ROBINS-I Tool; Table S6. Summary of estimates of meta-regression to assess the influence of smoking on $25(\mathrm{OH}) \mathrm{D}$ serum level.

Author Contributions: Conceptualization, V.M. and J.B.; methodology, V.M., S.L. and J.B.; software, V.M., L.P. and J.B.; validation, J.J.M. and J.B.; formal analysis, V.M., L.P. and J.B.; investigation, V.M. and S.L.; resources, none; data curation, V.M., S.L. and J.B.; writing-original draft preparation, V.M. and S.L.; writing-review and editing, J.B.; visualization, J.J.M.; supervision, J.B.; project administration, V.M.; funding acquisition, None. All authors have read and agreed to the published version of the manuscript.

Funding: This research received no external funding.

Conflicts of Interest: The authors declare no conflict of interest.

\section{References}

1. Borel, P.; Caillaud, D.; Cano, N.J. Vitamin D Bioavailability: State of the art. Crit. Rev. Food Sci. Nutr. 2015, 55, 1193-1205. [CrossRef] [PubMed]

2. Holick, F.M. Vitamin D Deficiency. N. Engl. J. Med. 2007, 357, 266-281. [CrossRef] [PubMed]

3. Holick, M.F.; Chen, T.C. Vitamin D deficiency: A worldwide problem with health consequences. Am. J. Clin. Nutr. 2008, 87, 1080-1086. [CrossRef] [PubMed]

4. Bischoff-Ferrari, H.A.; Kiel, D.P.; Dawson-Hughes, B.; Orav, J.E.; Li, R.; Spiegelman, D.; Dietrich, T.; Willett, W.C. Dietary calcium and serum 25-hydroxyvitamin D status in relation to BMD among U.S. adults. J. Bone Miner. Res. 2009, 24, 935-942. [CrossRef] [PubMed]

5. Reid, I.R.; Bolland, M.J.; Grey, A. Effects of vitamin D supplements on bone mineral density: A systematic review and meta-Analysis. Lancet 2014, 383, 146-155. [CrossRef]

6. Kogawa, M.; Findlay, D.M.; Anderson, P.H.; Ormsby, R.; Vincent, C.; Morris, H.A.; Atkins, G.J. Osteoclastic metabolism of 25(OH)-vitamin D3: A potential mechanism for optimization of bone resorption. Endocrinology 2010, 151, 4613-4625. [CrossRef]

7. Haussler, M.R.; Whitfield, G.K.; Kaneko, I.; Haussler, C.A.; Hsieh, D.; Hsieh, J.C.; Jurutka, P.W. Molecular mechanisms of vitamin D action. Calcif. Tissue Int. 2013, 92, 77-98. [CrossRef]

8. Girgis, C.M.; Clifton-Bligh, R.J.; Hamrick, M.W.; Holick, M.F.; Gunton, J.E. The roles of vitamin D in skeletal muscle: Form, function, and metabolism. Endocr. Rev. 2013, 34, 33-83. [CrossRef]

9. Bischoff-Ferrari, H.A.; Willett, W.C.; Wong, J.B.; Giovannucci, E.; Dietrich, T.; Dawson-Hughes, B. Fracture Prevention With Vitamin D Supplementation. JAMA 2005, 293, 2257. [CrossRef]

10. EFSA Panel on Dietetic Products; Nutrition and Allergies (EFSA NDA Panel); Turck, D.; Bresson, J.L.; Burlingame, B.; Dean, T.; Fairweather-Tait, S.; Heinonen, M.; Hirsch-Ernst, K.I.; Mangelsdorf, I.; et al. Update of the tolerable upper intake level for vitamin D for infants. EFSA J. 2018, 16, e05365.

11. Lanham-New, S.A.; Wilson, L.R. Vitamin D-has the new dawn for dietary recommendations arrived? Nutr. Bull. 2016, 41, 2-5. [CrossRef]

12. McKenna, M.J.; Murray, B. Vitamin D Deficiency; Springer: New York, NY, USA, 2014; ISBN 9781461486848.

13. Hilger, J.; Friedel, A.; Herr, R.; Rausch, T.; Roos, F.; Wahl, D.A.; Pierroz, D.D.; Weber, P.; Hoffmann, K. A systematic review of vitamin D status in populations worldwide. Br. J. Nutr. 2014, 111, 23-45. [CrossRef] [PubMed]

14. Mogire, R.M.; Mutua, A.; Kimita, W.; Kamau, A.; Bejon, P.; Pettifor, J.M.; Adeyemo, A.; Williams, T.N.; Atkinson, S.H. Prevalence of vitamin D deficiency in Africa: A systematic review and meta-analysis. Lancet Glob. Health 2020, 8, e134-e142. [CrossRef]

15. Darveau, R.P. Periodontitis: A polymicrobial disruption of host homeostasis. Nat. Rev. Microbiol. 2010, 8, 481-490. [CrossRef] [PubMed] 
16. Caton, J.G.; Armitage, G.; Berglundh, T.; Chapple, I.L.C.; Jepsen, S.; Kornman, K.S.; Mealey, B.L.; Papapanou, P.N.; Sanz, M.; Tonetti, M.S. A new classification scheme for periodontal and peri-implant diseases and conditions-Introduction and key changes from the 1999 classification. J. Periodontol. 2018, 45, 1-8. [CrossRef]

17. Kassebaum, N.J.; Bernabé, E.; Dahiya, M.; Bhandari, B.; Murray, C.J.L.; Marcenes, W. Global Burden of Severe Tooth Loss: A Systematic Review and Meta-analysis. JDR Clínical Res. Suppl. 2014, 93, 20s-28s. [CrossRef]

18. Pihlstrom, B.L.; Michalowicz, B.S.; Johnson, N.W. Periodontal diseases. Lancet 2005, 366, $1809-1820$. [CrossRef]

19. Ramseier, C.A.; Anerud, A.; Dulac, M.; Lulic, M.; Cullinan, M.P.; Seymour, G.J.; Faddy, M.J.; Bürgin, W.; Schätzle, M.; Lang, N.P. Natural history of periodontitis: Disease progression and tooth loss over 40 years. J. Clin. Periodontol. 2017, 44, 1182-1191. [CrossRef] [PubMed]

20. Helal, O.; Göstemeyer, G.; Krois, J.; Fawzy El Sayed, K.; Graetz, C.; Schwendicke, F. Predictors for tooth loss in periodontitis patients: Systematic review and meta-analysis. J. Clin. Periodontol. 2019, 46, 699-712. [CrossRef]

21. Graziani, F.; Karapetsa, D.; Alonso, B.; Herrera, D. Nonsurgical and surgical treatment of periodontitis: How many options for one disease? Periodontology 2000 2017, 75, 152-188. [CrossRef]

22. Najeeb, S.; Zafar, M.S.; Khurshid, Z.; Zohaib, S.; Almas, K. The role of nutrition in periodontal health: An update. Nutrients 2016, 8, 530. [CrossRef] [PubMed]

23. Jagelavičienè, E.; Vaitkevičienè, I.; Šilingaitè, D.; Šinkūnaitė, E.; Daugèlaitè, G. The relationship between vitamin D and periodontal pathology. Medicina 2018, 54, 45. [CrossRef] [PubMed]

24. Garcia, M.N.; Hildebolt, C.F.; Miley, D.D.; Dixon, D.A.; Couture, R.A.; Anderson Spearie, C.L.; Langenwalter, E.M.; Shannon, W.D.; Deych, E.; Mueller, C.; et al. One-Year Effects of Vitamin D and Calcium Supplementation on Chronic Periodontitis. J. Periodontol. 2011, 82, 25-32. [CrossRef]

25. Grant, W.B.; Boucher, B.J. Are hill's criteria for causality satisfied for vitamin D and periodontal disease? Dermatoendocrinology 2010, 2, 30-36. [CrossRef] [PubMed]

26. Stein, S.H.; Livada, R.; Tipton, D.A. Re-evaluating the role of vitamin D in the periodontium. J. Periodontal Res. 2014, 49, 545-553. [CrossRef] [PubMed]

27. Botelho, J.; Machado, V.; Proença, L.; Delgado, A.S.; Mendes, J.J. Vitamin D deficiency and oral health: A comprehensive review. Nutrients 2020, 12, 1471. [CrossRef] [PubMed]

28. Anbarcioglu, E.; Kirtiloglu, T.; Öztürk, A.; Kolbakir, F.; Acıkgöz, G.; Colak, R. Vitamin D deficiency in patients with aggressive periodontitis. Oral Dis. 2018, 25, 242-249. [CrossRef]

29. Agrawal, A.A.; Kolte, A.P.; Kolte, R.A.; Chari, S.; Gupta, M.; Pakhmode, R. Evaluation and comparison of serum vitamin $\mathrm{D}$ and calcium levels in periodontally healthy, chronic gingivitis and chronic periodontitis in patients with and without diabetes mellitus-a cross-sectional study. Acta Odontol. Scand. 2019, 77, 592-599. [CrossRef]

30. Ebersole, J.L.; Lambert, J.; Bush, H.; Huja, P.E.; Basu, A. Serum nutrient levels and aging effects on periodontitis. Nutrients 2018, 10, 1986. [CrossRef]

31. Isola, G.; Alibrandi, A.; Rapisarda, E.; Matarese, G.; Williams, R.C.; Leonardi, R. Association of vitamin D in patients with periodontitis: A cross-sectional study. J. Periodontal Res. 2020, 1-11. [CrossRef]

32. Ketharanathan, V.; Torgersen, G.R.; Petrovski, B.É.; Preus, H.R. Radiographic alveolar bone level and levels of serum 25-OH-Vitamin D 3 in ethnic Norwegian and Tamil periodontitis patients and their periodontally healthy controls. BMC Oral Health 2019, 19, 1-7. [CrossRef] [PubMed]

33. Costantini, E.; Sinjari, B.; Piscopo, F.; Porreca, A.; Reale, M.; Caputi, S.; Murmura, G. Evaluation of salivary cytokines and vitamin D levels in periodontopathic patients. Int. J. Mol. Sci. 2020, 21, 2669. [CrossRef]

34. Dietrich, T.; Joshipura, K.J.; Dawson-Hughes, B.; Bischoff-Ferrari, H.A. Association between serum concentrations of 25-hydroxyvitamin D 3 and periodontal disease in the US population. Am. J. Clin. Nutr. 2004, 80, 108-113. [PubMed]

35. Millen, A.E.; Hovey, K.M.; LaMonte, M.J.; Swanson, M.; Andrews, C.A.; Kluczynski, M.A.; Genco, R.J.; Wactawski-Wende, J. Plasma 25-Hydroxyvitamin D Concentrations and Periodontal Disease in Postmenopausal Women. J. Periodontol. 2013, 84, 1243-1256. [CrossRef]

36. Antonoglou, G.N.; Knuuttila, M.; Niemelä, O.; Raunio, T.; Karttunen, R.; Vainio, O.; Hedberg, P.; Ylöstalo, P.; Tervonen, T. Low serum level of 1,25(OH)2D is associated with chronic periodontitis. J. Periodontal Res. 2015, 50, 274-280. [CrossRef] [PubMed] 
37. Hu, X.; Niu, L.; Ma, C.; Huang, Y.; Yang, X.; Shi, Y.; Pan, C.; Liu, J.; Wang, H.; Li, Q.; et al. Calcitriol decreases live Porphyromonas gingivalis internalized into epithelial cells and monocytes by promoting autophagy. J. Periodontol. 2019, 91, 956-966. [CrossRef] [PubMed]

38. Han, J.; Cheng, C.; Zhu, Z.; Lin, M.; Zhang, D.X.; Wang, Z.M.; Wang, S. Vitamin D reduces the serum levels of inflammatory cytokines in rat models of periodontitis and chronic obstructive pulmonary disease. J. Oral Sci. 2019, 61, 53-60. [CrossRef]

39. Oh, C.; Kim, H.J.; Kim, H.M. Vitamin D maintains E-cadherin intercellular junctions by downregulating MMP-9 production in human gingival keratinocytes treated by TNF- $\alpha$. J. Periodontal Implant Sci. 2019, 49, 270-286. [CrossRef]

40. Wang, Q.; Zhou, X.; Zhang, P.; Zhao, P.; Nie, L.; Ji, N.; Ding, Y.; Wang, Q. 25-Hydroxyvitamin D3 positively regulates periodontal inflammaging via SOCS3/STAT signaling in diabetic mice. Steroids 2020, 156, 108570. [CrossRef]

41. Li, H.; Zhong, X.; Li, W.; Wang, Q. Effects of 1,25-dihydroxyvitamin on experimental periodontitis and ahr/nf-kb/nlrp3 inflammasome pathway in a mouse model. J. Appl. Oral Sci. 2019, 27, 1-10. [CrossRef]

42. van der Putten, G.J.; Vanobbergen, J.; De Visschere, L.; Schols, J.; de Baat, C. Association of some specific nutrient deficiencies with periodontal disease in elderly people: A systematic literature review. Nutrition 2009, 25, 717-722. [CrossRef]

43. Perić, M.; Cavalier, E.; Toma, S.; Lasserre, J.F. Serum vitamin D levels and chronic periodontitis in adult, Caucasian population-a systematic review. J. Periodontal Res. 2018, 53, 645-656. [CrossRef]

44. Pinto, J.P.N.S.; Goergen, J.; Muniz, F.W.M.G.; Haas, A.N. Vitamin D levels and risk for periodontal disease: A systematic review. J. Periodontal Res. 2018, 53, 298-305. [CrossRef] [PubMed]

45. Fakheran, O.; Khodadadi-Bohlouli, Z.; Khademi, A. Effect of Vitamin D level on periodontal treatment outcomes: A systematic review. Gen. Dent. 2019, 67, 64-67. [PubMed]

46. Higgins, P.T.; Green, S. Cochrane Handbook for Systematic Reviews of Interventions, 4th ed.; John Wiley \& Sons: Hoboken, NJ, USA, 2011.

47. Liberati, A.; Altman, D.G.; Tetzlaff, J.; Mulrow, C.; Gøtzsche, P.C.; Ioannidis, J.P.A.; Clarke, M.; Devereaux, P.J.; Kleijnen, J.; Moher, D. The PRISMA statement for reporting systematic reviews and meta-analyses of studies that evaluate health care interventions: Explanation and elaboration. PLoS Med. 2009, 6. [CrossRef] [PubMed]

48. OpenGrey. Available online: http://www.opengrey.eu (accessed on 20 April 2020).

49. Sterne, J.A.; Hernán, M.A.; Reeves, B.C.; Savović, J.; Berkman, N.D.; Viswanathan, M.; Henry, D.; Altman, D.G.; Ansari, M.T.; Boutron, I.; et al. ROBINS-I: A tool for assessing risk of bias in non-randomised studies of interventions. BMJ 2016, 355, 4-10. [CrossRef]

50. Hozo, S.P.; Djulbegovic, B.; Hozo, I. Estimating the mean and variance from the median, range, and the size of a sample. BMC Med. Res. Methodol. 2005, 5, 1-10. [CrossRef]

51. Schwarzer, G.; Carpenter, J.R.; Rücker, G. Meta-Analysis with R; Springer: Berlin/Heidelberg, Germany, 2015; ISBN 9783319214153.

52. Schwarzer, G. meta: An R Package for Meta-Analysis. R News 2007, 7, 40-45.

53. Higgins, J.P.T.; Altman, D.G.; Gøtzsche, P.C.; Jüni, P.; Moher, D.; Oxman, A.D. The Cochrane Collaboration 's tool for assessing risk of bias in randomised trials. BMJ Br. Med. J. 2011, 343, 1-9. [CrossRef]

54. Campbell, M.; McKenzie, J.E.; Sowden, A.; Katikireddi, S.V.; Brennan, S.E.; Ellis, S.; Hartmann-Boyce, J.; Ryan, R.; Shepperd, S.; Thomas, J.; et al. Synthesis without meta-analysis (SWiM) in systematic reviews: Reporting guideline. BMJ 2020, 368, 16890. [CrossRef]

55. Newman, M.G.; Weyant, R.; Hujoel, P. JEBDP Improves Grading System and Adopts Strength of Recommendation Taxonomy Grading (SORT) for Guidelines and Systematic Reviews. J. Evid. Based. Dent. Pract. 2007, 7, 147-150. [CrossRef] [PubMed]

56. Zhang, X.; Meng, H.; Sun, X.; Xu, L.; Zhang, L.; Shi, D.; Feng, X.; Lu, R.; Chen, Z. Elevation of vitamin D-binding protein levels in the plasma of patients with generalized aggressive periodontitis. J. Periodontal Res. 2012, 48, 74-79. [CrossRef] [PubMed]

57. Gumus, P.; Huseyinalemdaroglu, B.; Buduneli, N. The role of oxidative stress in the interaction of periodontal disease with systemic diseases or conditions. Oxid. Antioxid. Med. Sci. 2016, 5, 33. [CrossRef] 
58. Miricescu, D.; Totan, A.; Calenic, B.; Mocanu, B.; Didilescu, A.; Mohora, M.; Spinu, T.; Greabu, M. Salivary biomarkers: Relationship between oxidative stress and alveolar bone loss in chronic periodontitis. Acta Odontol. Scand. 2014, 72, 42-47. [CrossRef] [PubMed]

59. Laky, M.; Bertl, K.; Haririan, H.; Andrukhov, O.; Seemann, R.; Volf, I.; Assinger, A.; Gruber, R.; Moritz, A.; Rausch-Fan, X. Serum levels of 25-hydroxyvitamin D are associated with periodontal disease. Clin. Oral Investig. 2017, 21, 1553-1558. [CrossRef]

60. Abreu, O.J.; Tatakis, D.N.; Elias-Boneta, A.R.; López Del Valle, L.; Hernandez, R.; Pousa, M.S.; Palacios, C. Low vitamin D status strongly associated with periodontitis in Puerto Rican adults. BMC Oral Health 2016, 16, 1-5. [CrossRef]

61. Joseph, R.; Nagrale, A.; Joseraj, M.; Pradeep Kumar, K.; Kaziyarakath, J.; Chandini, R. Low levels of serum Vitamin D in chronic periodontitis patients with type 2 diabetes mellitus: A hospital-based cross-sectional clinical study. J. Indian Soc. Periodontol. 2015, 19, 501-506. [CrossRef]

62. Yuce, H.B.; Gokturk, O.; Turkal, H.A.; Inanir, A.; Benli, I.; Demir, O. Assessment of local and systemic 25-hydroxy-vitamin D, RANKL, OPG, and TNF levels in patients with rheumatoid arthritis and periodontitis. J. Oral Sci. 2017, 59, 397-404. [CrossRef]

63. Gao, W.; Tang, H.; Wang, D.; Zhou, X.; Song, Y.; Wang, Z. Effect of short-term vitamin D supplementation after nonsurgical periodontal treatment: A randomized, double-masked, placebo-controlled clinical trial. J. Periodontal Res. 2020, 55, 354-362. [CrossRef]

64. Perayil, J.; Menon, K.S.; Kurup, S.; Thomas, A.E.; Fenol, A.; Vyloppillil, R.; Bhaskar, A.; Megha, S. Influence of Vitamin D \& calcium supplementation in the management of periodontitis. J. Clin. Diagn. Res. 2015, 9, ZC35-ZC38.

65. Bonnet, C.; Rabbani, R.; Moffatt, M.E.K.; Kelekis-Cholakis, A.; Schroth, R.J. The Relation Between Periodontal Disease and Vitamin D. J. Can. Dent. Assoc. 2019, 84, j4. [PubMed]

66. Khammissa, R.A.G.; Ballyram, R.; Jadwat, Y.; Fourie, J.; Lemmer, J.; Feller, L. Vitamin D Deficiency as It Relates to Oral Immunity and Chronic Periodontitis. Int. J. Dent. 2018, 2018. [CrossRef] [PubMed]

67. Bashutski, J.D.; Eber, R.M.; Kinney, J.S.; Benavides, E.; Maitra, S.; Braun, T.M.; Giannobile, W.V.; McCauley, L.K. Teriparatide and Osseous Regeneration in the Oral Cavity. N. Engl. J. Med. J Med. 2010, 363, 2396-2405. [CrossRef] [PubMed]

68. Bashutski, J.D.; Eber, R.M.; Kinney, J.S.; Benavides, E.; Maitra, S.; Braun, T.M.; Giannobile, W.V.; McCauley, L.K. The impact of vitamin D status on periodontal surgery outcomes. J. Dent. Res. 2011,90, 1007-1012. [CrossRef]

69. Tada, H.; Shimizu, T.; Nagaoka, I.; Takada, H. Vitamin D3 analog maxacalcitol (OCT) induces hCAP-18/LL-37 production in human oral epithelial cells. Biomed. Res. 2016, 37, 199-205. [CrossRef]

70. Tada, H.; Shimizu, T.; Matsushita, K.; Takada, H. Porphyromonas gingivalis-induced IL-33 down-regulates hCAP-18/LL-37 production in human gingival epithelial cells. Biomed. Res. 2017, 38, 167-173. [CrossRef]

71. Gao, Z.; Liu, K.; Meng, H. Preliminary investigation of the vitamin D pathway in periodontal connective tissue cells. J. Periodontol. 2018, 89, 294-302. [CrossRef]

72. Zhou, X.; Zhang, P.; Wang, Q.; Xia, S.; Ji, N.; Ding, Y.; Wang, Q. 25-hydroxyvitamin D3 alleviates experimental periodontitis via promoting expression of cathelicidin in mice with type 2 diabetic mellitus. J. Nutr. Sci. Vitaminol. (Tokyo) 2018, 64, 307-315. [CrossRef]

73. Bayirli, B.A.; Öztürk, A.; Avci, B. Serum vitamin D concentration is associated with antimicrobial peptide level in periodontal diseases. Arch. Oral Biol. 2020, 117, 104827. [CrossRef]

74. Tonetti, M.S.; Greenwell, H.; Kornman, K.S. Staging and grading of periodontitis: Framework and proposal of a new classification and case definition. J. Clin. Periodontol. 2018, 45, 149-161. [CrossRef]

75. Graetz, C.; Mann, L.; Krois, J.; Sälzer, S.; Kahl, M.; Springer, C.; Schwendicke, F. Comparison of periodontitis patients' classification in the 2018 versus 1999 classification. J. Clin. Periodontol. 2019, 46, 908-917. [CrossRef] [PubMed]

76. Botelho, J.; Machado, V.; Proença, L.; Mendes, J.J. The 2018 periodontitis case definition improves accuracy performance of full-mouth partial diagnostic protocols. Sci. Rep. 2020, 10, 7093. [CrossRef]

77. Varela-López, A.; Navarro-Hortal, M.D.; Giampieri, F.; Bullón, P.; Battino, M.; Quiles, J.L. Nutraceuticals in Periodontal Health: A Systematic Review on the Role of Vitamins in Periodontal Health Maintenance. Molecules 2018, 23, 1226. [CrossRef] [PubMed]

78. Garcia, M.N.; Hildebolt, C. Limited Evidence Suggests That Vitamin D May Help Prevent and Treat Periodontal Disease in Adults. J. Evid. Based Dent. Pract. 2020, 20, 101342. [CrossRef] [PubMed] 
79. Jassil, N.K.; Sharma, A.; Bikle, D.; Wang, X. Vitamin D binding protein and 25-hydroxyvitamin D levels: Emerging clinical applications. Endocr. Pract. 2017, 23, 605-613. [CrossRef]

80. Kassebaum, N.J.; Bernabé, E.; Dahiya, M.; Bhandari, B.; Murray, C.J.L.; Marcenes, W. Global Burden of Severe Periodontitis in 1990-2010. J. Dent. Res. 2014, 93, 1045-1053. [CrossRef]

81. Bae, S.-C.; Lee, Y.H. Association between Vitamin D level and/or deficiency, and systemic lupus erythematosus: A meta-analysis. Cell. Mol. Biol. 2018, 51,7-13. [CrossRef]

82. Lee, H.J.; Je, D.I.; Won, S.J.; Paik, D.I.; Bae, K.H. Association between Vitamin D deficiency and periodontal status in current smokers. Community Dent. Oral Epidemiol. 2015, 43, 471-478. [CrossRef]

83. Lin, J.; Liu, J.; Davies, M.L.; Chen, W. Serum Vitamin D level and rheumatoid arthritis disease activity: Review and meta-analysis. PLoS ONE 2016, 11, e0146351. [CrossRef]

84. Wang, L.; Song, Y.; Manson, J.A.E.; Pilz, S.; März, W.; Michaëlsson, K.; Lundqvist, A.; Jassal, S.K.; Barrett-Connor, E.; Zhang, C.; et al. Circulating 25-Hydroxy-Vitamin D and risk of cardiovascular disease: A meta-analysis of prospective studies. Circ. Cardiovasc. Qual. Outcomes 2012, 5, 819-829. [CrossRef]

85. Zhou, R.; Wang, M.; Huang, H.; Li, W.; Hu, Y.; Wu, T. Lower vitamin D status is associated with an increased risk of ischemic stroke: A systematic review and meta-analysis. Nutrients 2018, 10, 277. [CrossRef] [PubMed]

86. Brøndum-Jacobsen, P.; Nordestgaard, B.G.; Schnohr, P.; Benn, M. 25-Hydroxyvitamin D and symptomatic ischemic stroke: An original study and meta-analysis. Ann. Neurol. 2013, 73, 38-47. [CrossRef] [PubMed]

87. Autier, P.; Boniol, M.; Pizot, C.; Mullie, P. Vitamin D status and ill health: A systematic review. Lancet Diabetes Endocrinol. 2014, 2, 76-89. [CrossRef]

88. Lips, P.; Eekhoff, M.; van Schoor, N.; Oosterwerff, M.; de Jongh, R.; Krul-Poel, Y.; Simsek, S. Vitamin D and type 2 diabetes. J. Steroid Biochem. Mol. Biol. 2017, 173, 280-285. [CrossRef]

89. Santos, R.K.F.; Brandão-Lima, P.N.; Tete, R.M.D.D.; Freire, A.R.S.; Pires, L.V. Vitamin D ratio and glycaemic control in individuals with type 2 diabetes mellitus: A systematic review. Diabetes. Metab. Res. Rev. 2018, 34, 1-11. [CrossRef]

90. Fabisiak, N.; Fabisiak, A.; Watala, C.; Fichna, J. Fat-soluble Vitamin Deficiencies and Inflammatory Bowel Disease: Systematic Review and Meta-Analysis. J. Clin. Gastroenterol. 2017, 51, 878-889. [CrossRef]

91. Del Pinto, R.; Pietropaoli, D.; Chandar, A.K.; Ferri, C.; Cominelli, F. Association between Inflammatory Bowel Disease and Vitamin D Deficiency: A Systematic Review and Meta-Analysis. Inflamm. Bowel Dis. 2015, 21, 2708-2717. [CrossRef]

92. Lerchbaum, E.; Rabe, T. Vitamin D and female fertility. Curr. Opin. Obstet. Gynecol. 2014, 26, 145-150. [CrossRef]

93. Trummer, C.; Pilz, S.; Schwetz, V.; Obermayer-Pietsch, B.; Lerchbaum, E. Vitamin D, PCOS and androgens in men: A systematic review. Endocr. Connect. 2018, 7, R95-R113. [CrossRef]

94. He, C.; Lin, Z.; Robb, S.W.; Ezeamama, A.E. Serum vitamin d levels and polycystic ovary syndrome: A systematic review and meta-analysis. Nutrients 2015, 7, 4555-4577. [CrossRef]

95. Irani, M.; Merhi, Z. Role of vitamin D in ovarian physiology and its implication in reproduction: A systematic review. Fertil. Steril. 2014, 102, 460-468. [CrossRef] [PubMed]

96. Klingberg, E.; Oleröd, G.; Konar, J.; Petzold, M.; Hammarsten, O. Seasonal variations in serum 25-hydroxy vitamin D levels in a Swedish cohort. Endocrine 2015, 49, 800-808. [CrossRef] [PubMed]

97. Yousefzadeh, P.; Shapses, S.A.; Wang, X. Vitamin D binding protein impact on 25-hydroxyvitamin D levels under different physiologic and pathologic conditions. Int. J. Endocrinol. 2014, 2014, 1-6. [CrossRef] [PubMed]

98. Muñoz Aguilera, E.; Suvan, J.; Buti, J.; Czesnikiewicz-Guzik, M.; Barbosa Ribeiro, A.; Orlandi, M.; Guzik, T.J.; Hingorani, A.D.; Nart, J.; D'Aiuto, F. Periodontitis is associated with hypertension: A systematic review and meta-analysis. Cardiovasc. Res. 2020, 116, 28-39. [CrossRef] [PubMed]

99. Machado, V.; Aguilera, E.M.; Hussain, S.B. Association between Periodontitis and High Blood Pressure: Results from the Study of Periodontal Health in Almada-Seixal (SoPHiAS). J. Clin. Med. 2020, 9, 1585. [CrossRef]

100. Machado, V.; Botelho, J.; Lopes, J.; Patrão, M.; Alves, R.; Chambrone, L.; Alcoforado, G.; Mendes, J.J. Periodontitis impact in interleukin-6 serum levels in solid organ transplanted patients: A systematic review and meta-analysis. Diagnostics 2020, 10, 184. [CrossRef] 
101. Machado, V.; Escalda, C.; Proença, L.; Mendes, J.J.; Botelho, J. Is There a Bidirectional Association between Polycystic Ovarian Syndrome and Periodontitis? A Systematic Review and Meta-analysis. J. Clin. Med. 2020, 9, 1961. [CrossRef]

102. Hussain, S.B.; Botelho, J.; Machado, V.; Zehra, S.A.; Mendes, J.J.; Ciurtin, C.; Orlandi, M.; Aiuto, F.D. Is there a bidirectional association between rheumatoid arthritis and periodontitis? A systematic review and meta-analysis. In Seminars in Arthritis and Rheumatism; WB Saunders: Philadelphia, PA, USA, 2020.

103. Machado, V.; Lopes, J.; Patrão, M.; Botelho, J.; Proença, L.; Mendes, J.J. Validity of the association between periodontitis and female infertility conditions: A concise review. Reproduction 2020. [CrossRef]

104. Sanz, M.; Marco del Castillo, A.; Jepsen, S.; Gonzalez-Juanatey, J.R.; D'Aiuto, F.; Bouchard, P.; Chapple, I.; Dietrich, T.; Gotsman, I.; Graziani, F.; et al. Periodontitis and cardiovascular diseases: Consensus report. J. Clin. Periodontol. 2020, 47, 268-288. [CrossRef]

105. Preshaw, P.M.; Bissett, S.M. Periodontitis and diabetes. Br. Dent. J. 2019, 227, 577-584. [CrossRef]

106. Snellman, G.; Melhus, H.; Gedeborg, R.; Byberg, L.; Berglund, L.; Wernroth, L.; Michaëlsson, K. Determining vitamin D status: A comparison between commercially available assays. PLoS ONE 2010, 5, 3-9. [CrossRef]

107. Zhang, X.; Meng, H.; Xu, L.; Zhang, L.; Shi, D.; Feng, X.; Lu, R.; Chen, Z. Vitamin D-binding protein levels in plasma and gingival crevicular fluid of patients with generalized aggressive periodontitis. Int. J. Endocrinol. 2014, 2014. [CrossRef] [PubMed]

108. Rafique, S.; Hingorjo, M.R.; Mumtaz, M.; Qureshi, M.A. The relationship of 1,25-dihydroxyvitamin D and vitamin D binding protein in periodontitis. Pakistan J. Med. Sci. 2019, 35, 847-851. [CrossRef] [PubMed]

109. Schwarz, F.; Derks, J.; Monje, A.; Wang, H.L.; Wolfgang, J. Peri-implantitis. J. Clin. Periodontol. 2018, 45, S246-S266. [CrossRef] [PubMed]

110. Sgolastra, F.; Petrucci, A.; Severino, M.; Gatto, R.; Monaco, A. Periodontitis, implant loss and peri-implantitis: A meta-analysis. Clin. Oral Implants Res. 2013, 26, e8-e16. [CrossRef]

111. Acipinar, S.; Karsiyaka Hendek, M.; Olgun, E.; Kisa, U. Evaluation of FGF-23 and 25(OH)D3 levels in peri-implant sulcus fluid in peri-implant health and diseases. Clin. Implant Dent. Relat. Res. 2019, 21, 1106-1112. [CrossRef]

(C) 2020 by the authors. Licensee MDPI, Basel, Switzerland. This article is an open access article distributed under the terms and conditions of the Creative Commons Attribution (CC BY) license (http://creativecommons.org/licenses/by/4.0/). 